\title{
Comparison of Measured and FAO-56 Modeled Evaporation from Bare Soil
}

\author{
A. J. Mutziger ${ }^{1}$; C. M. Burt' ${ }^{2}$ D. J. Howes ${ }^{3}$; and R. G. Allen ${ }^{4}$
}

\begin{abstract}
This paper evaluates how well the FAO-56 style soil water evaporation model simulates measurements of evaporation $(E)$ from bare soil. Seven data sets were identified from the literature and in all but one case, the individuals who took the measurements were contacted and they provided the writers with specific weather and soils data for model input. Missing weather and soils data were obtained from online sources or from the National Climatic Data Center. Simulations for three possible variations of soil data were completed and compared. The measured and the FAO-56 simulated E/ETo and cumulative evaporation trends and values were similar. Specifically, the average evaporation weighted percent difference between the measured and the simulated cumulative evaporation was between -7.5 and $-0.5 \%$. This evaluation suggests model accuracy of about $\pm 15 \%$ with the use of sound weather data and a fairly generalized understanding of soil properties in the location being evaluated.
\end{abstract}

CE Database subject headings: Evapotranspiration; Evaporation; Lysimeters; Irrigation scheduling; Soil water; Transpiration; Measurement.

\section{Introduction}

In California and many other states, data from a network of agricultural weather stations is accessible via the World Wide Web to provide estimates of local reference evapotranspiration which, when coupled with crop coefficient $\left(K_{c}\right)$ values, can be used for irrigation scheduling and water management. The California Irrigation Management Information System (CIMIS) weather stations identify the water use of a $10-15 \mathrm{~cm}$ tall unstressed irrigated grass for the reference evapotranspiration (ETo) (Eching and Moellenberndt 1998). ETo is estimated using solar radiation, air temperature, vapor pressure, and wind speed measurements as inputs into a version of the Penman equation modified by Pruitt and Doorenbos (1977). Multiplying the local $K_{c}$ value for the crop of interest by the local daily ETo value provides an estimate of daily crop evapotranspiration $\left(\mathrm{ET}_{c}\right)$.

\footnotetext{
${ }^{1}$ Air Quality Specialist, San Luis Obispo County Air Pollution Control District, San Luis Obispo, CA 93401; formerly, Irrigation Technician II, Irrigation Training and Research Center (ITRC), California Polytechnic State Univ. (Cal Poly), San Luis Obispo, CA 93407.

${ }^{2}$ Chairman, Irrigation Training and Research Center, BioResource and Agricultural Engineering Dept., California Polytechnic State Univ., San Luis Obispo, CA 93407. E-mail: cburt@calpoly.edu

${ }^{3}$ Irrigation Support Engineer III, Irrigation Training and Research Center, California Polytechnic State Univ. (Cal Poly), San Luis Obispo, CA 93407. E-mail: djhowes@calpoly.edu

${ }^{4}$ Professor of Water Resources Engineering, Univ. of Idaho, Kimberly Research and Extension Center, 3793 N. 3600 E., Kimberly, ID 83341. E-mail: rallen@kimberly.uidaho.edu
}

FAO-56 (Allen et al. 1998) offers a method for dividing $\mathrm{ET}_{c}$ into evaporation $(E)$ and transpiration $(T)$ components. This is done by splitting $K_{c}$ into two terms, the basal crop coefficient $\left(K_{c b}\right)$ and the soil evaporation coefficient $\left(K_{e}\right)$, where $K_{c}=K_{c b}$ $+K_{e}$. This dual $K_{c}$ approach was used for cumulative evaporation predictions in a CALFED/ARI Evaporation Study by Cal Poly Irrigation Training and Research Center (ITRC) (Burt et al. 2002) that estimated the amount of evaporation from California agricultural lands under three rainfall scenarios.

Allen et al. (2000) compared the predicted evaporation using these two ET partitioning methods with Kimberly, Id. data sets. The results indicate that the FAO-56 estimated cumulative soil evaporation for the growing season was about two times greater than that calculated with the Wright (1982) method that uses a time-based decay function. Since these data were collected on large precision weighing lysimeters that measured $E$ and $T$ collectively, there was no conclusive evidence as to which method provides a more accurate partitioning prediction. Both of these methods neglect diffusive water losses (from deep soil) that comprise part of the total evaporation component. These diffusive losses may be $5-10 \%$ of total ET (Allen, personal communication, 2001).

This paper is a companion paper to another written by Allen et al. (2005). Allen et al. (2005) introduce the FAO-56 dual crop coefficient procedure and associated two-stage evaporation model and algorithms that were used in the Cal Poly ITRC CALFED/ ARI Evaporation Study. Allen et al. (2005) also recommend parameter values, and demonstrates the integration of the procedure to create $K_{c}$ at the beginning of the season. That paper also introduces an expansion of the FAO-56 evaporation model to consider three-stage evaporation. The two- and three-stage models are also described in Chapter 6 and in Appendix B of the Cal Poly ITRC CALFED/ARI Evaporation Study report (Burt et al. 2002).

The purpose of this study was to provide an independent evaluation of how the FAO-56 style model predicts bare soil evaporation. Measured bare soil evaporation data sets (identified in the literature) were compared to simulations of those evapora- 
Table 1. Summary of Measured Bare Soil Evaporation Data Sets Used to Evaluate the Modified FAO-56 Model

\begin{tabular}{|c|c|c|c|c|}
\hline $\begin{array}{l}\text { Data set } \\
\text { number }\end{array}$ & Source & Location & Soil type & Evaporation measurement method \\
\hline 1 & Ritchie (1972) & Temple, Tex. & $\begin{array}{l}\text { Houston black clay; } 55 \% \\
\text { fine montmorillonitic clay }\end{array}$ & Lysimeter \\
\hline 2 & Parlange et al. (1992) & Davis, Calif & Yolo clay loam & Lysimeter \\
\hline $\begin{array}{l}3 \\
4 \\
5\end{array}$ & Howell et al. (1995) & Bushland, Tex. & Pullman clay loam & Lysimeter \\
\hline 6 & $\begin{array}{l}\text { Wright (1982, } \\
\text { personal communication, 2001) }\end{array}$ & Kimberly, Id. & Portneuf silt loam & Lysimeter \\
\hline 7 & Farahani and Bausch (1995) & Fort Collins, Colo. & Sandy clay loam ${ }^{a}$ & Bowen Ratio \\
\hline
\end{tabular}

tion events. Three types of simulations were used, which differed in their methods of defining the required soil parameters used in the FAO-56 model.

\section{Method}

To assess the effectiveness of the FAO-56 style model in simulating bare soil evaporation, measured bare or near-bare soil (when the Leaf Area Index $\leqslant 0.15$ ) evaporation events found in the literature were compared to simulations of these events. Data from

Table 2. Summary for Data Set 1: Houston Black Clay

\begin{tabular}{|c|c|}
\hline Parameter & Parameter values for data set \\
\hline Data set number & 1 \\
\hline Source & Ritchie (1972) \\
\hline Location & Temple, Tex. \\
\hline Soil & $\begin{array}{l}\text { Houston black clay; } 55 \% \text { fine } \\
\text { montmorillonitic clay }\end{array}$ \\
\hline Supporting weather data & $\begin{array}{l}\text { Ft. Hood, Tex.; W. of Temple; from } \\
\text { NOAA }\end{array}$ \\
\hline $\begin{array}{l}\text { Evaportation } \\
\text { measurement method }\end{array}$ & $\begin{array}{c}1.83 \mathrm{~m} \times 1.83 \mathrm{~m} \times 1.22 \mathrm{~m} \text { deep } \\
\text { lysimeter; backfilled by layers } \\
\text { using saturated sieved soil from } \\
\text { pit }\end{array}$ \\
\hline Start date & April 27, 1969 \\
\hline Date end & May 8, 1969 \\
\hline Total days & 12 \\
\hline $\begin{array}{l}\text { Reported preirrigation } \\
\text { volumetric soil water }\left(\mathrm{m}^{3} \mathrm{~m}^{-3}\right)\end{array}$ & Not stated \\
\hline $\begin{array}{l}\text { Reported volumetric soil water } \\
\text { at field capacity }\left(\mathrm{m}^{3} \mathrm{~m}^{-3}\right)\end{array}$ & Not stated \\
\hline $\begin{array}{l}\text { Reported volumetric soil water at } \\
\text { permanent wilting point }\left(\mathrm{m}^{3} \mathrm{~m}^{-3}\right)\end{array}$ & Not stated \\
\hline $\begin{array}{l}\text { Rain; Amount ( } \mathrm{mm} \text { ) and number } \\
\text { of events: Start to end }\end{array}$ & $48.4,6$ \\
\hline $\begin{array}{l}\text { Irrigation: Amount (mm) and } \\
\text { number of events: Start to end }\end{array}$ & None \\
\hline Crop & Sorghum \\
\hline Planting date & Not stated \\
\hline Emergence date & April 10, 1969 \\
\hline Leaf area index (LAI) at data end ${ }^{\mathrm{a}}$ & 0.15 \\
\hline Other measured LAI & 0.03 April 27, 1969 \\
\hline
\end{tabular}

five sources presented seven evaporation events using either lysimeters to measure water input and daily evaporation or Bowen Ratio equipment to estimate the daily evaporation from 12-h measurements. Table 1 summarizes general information regarding each of these studies, while Tables 2-6 present detailed information regarding each study.

The weather, irrigation, and evaporation data required to run the comparison simulations were provided by the scientists (personal communication) who published or made the evaporation measurements, except for the Ritchie (1972) paper, which contained much of the necessary data. When required, additional weather data were obtained using the World Wide Web sites for CIMIS (2001a, b) and Colorado Agricultural Meteorological Net-

Table 3. Summary for Data Set 2: Yolo Clay Loam

\begin{tabular}{|c|c|}
\hline Parameter & Parameter values for data set \\
\hline Data set number & 2 \\
\hline Source & Parlange and Katul (1992) \\
\hline Location & Davis, Calif. \\
\hline Soil & Yolo clay loam \\
\hline Supporting weather data & CIMIS Sta No. 6-Davis, Calif. \\
\hline $\begin{array}{l}\text { Evaporation measurement } \\
\text { method }\end{array}$ & $6 \mathrm{~m}$ diameter $\times 1 \mathrm{~m}$ deep lysimeter \\
\hline Start date & September 14,1990 \\
\hline Date end & September 23, 1990 \\
\hline Total days & 10 \\
\hline $\begin{array}{l}\text { Reported preirrigation } \\
\text { volumetric soil water }\left(\mathrm{m}^{3} \mathrm{~m}^{-3}\right)\end{array}$ & $\begin{array}{c}\text { September 13, } 19900.31: \\
0-0.75 \text { m deep }\end{array}$ \\
\hline $\begin{array}{l}\text { Reported volumetric soil water } \\
\text { at field capacity }\left(\mathrm{m}^{3} \mathrm{~m}^{-3}\right)\end{array}$ & $\begin{array}{c}0.26 \text { at }-1 / 3 \text { bar; } 0-0.3 \mathrm{~m} \text { deep } \\
\text { (the writers note that this looks too } \\
\text { low for a clay loam, but these are } \\
\text { the values indicated from neutron } \\
\text { probe readings) }\end{array}$ \\
\hline $\begin{array}{l}\text { Reported volumetric soil water at } \\
\text { permanent wilting point }\left(\mathrm{m}^{3} \mathrm{~m}^{-3}\right)\end{array}$ & 0.15 at -15 bar; $0-0.3 \mathrm{~m}$ deep \\
\hline $\begin{array}{l}\text { Rain: Amount (mm) and number } \\
\text { of events: Start to end }\end{array}$ & $18.1,1$ \\
\hline $\begin{array}{l}\text { Irrigation: Amount }(\mathrm{mm}) \text { and } \\
\text { number of events: Start to end }\end{array}$ & None \\
\hline Crop & None \\
\hline \multicolumn{2}{|l|}{ Planting date } \\
\hline \multicolumn{2}{|l|}{ Emergence date } \\
\hline \multirow{2}{*}{\multicolumn{2}{|c|}{ Leaf area index (LAI) at data end }} \\
\hline & \\
\hline
\end{tabular}


Table 4. Summary for Data Sets 3, 4, and 5: Pullman Clay Loam

\begin{tabular}{|c|c|c|c|}
\hline Parameter & & Parameter values for data sets & \\
\hline Data set number & 3 & 4 & 5 \\
\hline Source & & Howell et al. (1995) & \\
\hline Location & & Bushland, Tex. & \\
\hline Soil & & Pullman clay loam & \\
\hline Supporting weather data & & $\begin{array}{l}\text { 1. On site measurements } \\
\text { 2. Amarillo Int. Airport, } 15 \text { miles east; Acquired } \\
\text { from NOAA }\end{array}$ & \\
\hline Evaporation measurement method & & $\begin{array}{c}\text { Avg. from two } 3 \mathrm{~m} \times 3 \mathrm{~m} \times 2.3 \mathrm{~m} \text { deep lysimeter } \\
\text { undisturbed } \\
\text { soil monoliths }\end{array}$ & \\
\hline Start date & October 7, 1989 & September 18,1991 & September 27, 1992 \\
\hline Date end & November 6, 1989 & October 28, 1991 & November 5, 1992 \\
\hline Total days & 31 & 41 & 40 \\
\hline $\begin{array}{l}\text { Reported preirrigation volumetric soil } \\
\text { water }\left(\mathrm{m}^{3} \mathrm{~m}^{-3}\right)\end{array}$ & $\begin{array}{l}\text { October } 13,1989^{\mathrm{d}} \\
0.36: 0-0.3 \mathrm{~m} \text { and } \\
0.24: 0.3-1.9 \mathrm{~m}\end{array}$ & Not measured & $\begin{array}{l}\text { October } 9,1992^{\mathrm{e}} \\
0.29: 0-0.2 \mathrm{~m} \\
\text { and } \\
0.32: 0.2-2 \mathrm{~m}\end{array}$ \\
\hline $\begin{array}{l}\text { Reported volumetric soil water at field } \\
\text { capacity }\left(\mathrm{m}^{3} \mathrm{~m}^{-3}\right)\end{array}$ & & 0.338 ; from 0 to $1.6 \mathrm{~m}$ deep & \\
\hline $\begin{array}{l}\text { Reported volumetric soil water at } \\
\text { permanent wilting point }\left(\mathrm{m}^{3} \mathrm{~m}^{-3}\right)\end{array}$ & & 0.216 ; from 0 to $1.6 \mathrm{~m}$ deep & \\
\hline $\begin{array}{l}\text { Rain: Amount (mm) and number of events: } \\
\text { Start to end }\end{array}$ & $13.0,5$ & $25.3,6$ & $13.0,6$ \\
\hline $\begin{array}{l}\text { Irrigation: Amount }(\mathrm{mm}) \text { and number of } \\
\text { events: Start to end }\end{array}$ & $61.1,4$ & $79.5,4$ & $82.7,4$ \\
\hline Crop & & Winter wheat & \\
\hline Planting date & October 10,1989 & September 27, 1991 & September 29, 1992 \\
\hline Emergence date & October 18,1989 & October 7, 1991 & October 9, 1992 \\
\hline Leaf area index (LAI) at data end ${ }^{\mathrm{f}}$ & Approx 0.15 & $<0.15$ & Approx 0.15 \\
\hline Other measured LAI & Not measured & $\begin{array}{l}0.4 \text { on December 5, } \\
1991\end{array}$ & $\begin{array}{c}0.13 \text { on November 2, } \\
1992\end{array}$ \\
\hline
\end{tabular}

a1989: Averages of lysimeter data are from NW Lysimeter Wheat-Irrigated and SW Lysimeter Wheat—Dryland; irrigations for the two treatments were matched during the fall and winter.

${ }^{b}$ 1991: Averages of lysimeter data are from SE Lysimeter Wheat—Deficit Irrigated and NE Lysimeter Wheat—Irrigated; irrigations for the two treatments were matched during the fall and winter.

'1992: Averages of lysimeter data are from NW Lysimeter Wheat—Dryland and SW Lysimeter Wheat—Irrigated; irrigations for the two treatments were matched during the fall and winter.

${ }^{\mathrm{d}}$ Measured before a $10.3 \mathrm{~mm}$ irrigation on October 13, 1989 and after a $1 \mathrm{~mm}$ rain on October 5, 1989, a $0.5 \mathrm{~mm}$ rain on October 6, 1989 , and a $0.5 \mathrm{~mm}$ rain on October 10, 1989.

${ }^{\mathrm{e}}$ Measured before $11 \mathrm{~mm}$ irrigation on October 9, 1992 and after a $38.8 \mathrm{~mm}$ irrigation on October 2, 1992 and a $7.5 \mathrm{~mm}$ rain on October 7, 1992.

${ }^{\mathrm{f}} E$ and $T$ data as partitioned in Ritchie (1972) indicated that loss from transpiration is very small when the leaf area index is 0.15 or less.

work (CoAgMet) (2001) or by requesting hard copies of data not available on the web from the National Climatic Data Center. Specific contact and WWW links for these sources are found in the reference section of this paper (NOAA 2001; USDA-NRCS 2001). CoAgMet solar radiation data were corrected due to obvious discrepancies from theoretical incoming solar radiation, and grass reference evapotranspiration (ETo) was recalculated using the FAO-56 Penman-Monteith equation with hourly time steps.

The required weather data for the simulations were

1. Occurrence dates and amounts of precipitation or irrigation $(\mathrm{mm} / \mathrm{d})$;

2. Average daily wind speed $(\mathrm{m} / \mathrm{s})$;

3. Minimum daily relative humidity $(\%)$; and

4. Daily grass reference evapotranspiration, ETo $(\mathrm{mm} / \mathrm{d})$.

The required soil data were

1. The effective depth of soil evaporation layer $\left(Z_{e}, \mathrm{~m}\right)$;

2. Stage 1 readily evaporable water (REW, $\mathrm{mm})$;
3. Total evaporable water through evaporation Stages 1 and 2 $\left(\mathrm{TEW}_{2}, \mathrm{~mm}\right)$;

4. Total evaporable water through evaporation Stages 1, 2, and $3\left(\mathrm{TEW}_{3}, \mathrm{~mm}\right)$;

5. Evaporation reduction coefficient $\left(K_{r 2}\right)$ at the end of Stage 2 and beginning of Stage $3\left(K_{r 2}=0\right.$ if there is no Stage 3$)$. See Fig. 1; and

6. Cracking nature of the soil, not required, but offers insight into Stage 3 evaporation potential.

Unlike the weather data, which are generally well defined using the available sources, data for the specific soil at a location are often not readily available and may vary to some degree with time or management practices. In this evaluation, required soil data were obtained with three different methods and provided three series of simulations to compare against the measured evaporation amounts. Specifically, the measured and FAO-56 simulated ratio of daily $E$ to ETo and cumulative $E$ for the events were 
Table 5. Summary for Data Set 6: Portneuf Silt Loam

\begin{tabular}{|c|c|}
\hline Parameter & Parameter Values for Data Set \\
\hline Data set number & 6 \\
\hline Source & $\begin{array}{l}\text { Wright (1982, } \\
\text { personal communication, 2001); } \\
\text { Allen (personal communication, } \\
\text { 2001) }\end{array}$ \\
\hline Location & Kimberly, Id. \\
\hline Soil & Portneuf silt loam \\
\hline Supporting weather data & $\begin{array}{c}\text { National Wheather Serv. } 0.6 \mathrm{~m} \\
\text { north }\end{array}$ \\
\hline $\begin{array}{l}\text { Evaporation } \\
\text { measurement method }\end{array}$ & $\begin{array}{c}1.83 \mathrm{~m} \times 1.83 \mathrm{~m} \times 1.22 \mathrm{~m} \text { lysimeter; } \\
\text { backfilled by layers, compacted to } \\
\text { original bulk density, and } \\
\text { saturated with bottom excess water } \\
\text { removed using sintered extraction } \\
\text { candles }\end{array}$ \\
\hline Start date & August 1, 1977 \\
\hline Date end & September 24, 1977 \\
\hline Total days & 55 \\
\hline $\begin{array}{l}\text { Reported preirrigation } \\
\text { volumetric soil water }\left(\mathrm{m}^{3} \mathrm{~m}^{-3}\right)\end{array}$ & $0.05-0.1$ \\
\hline $\begin{array}{l}\text { Reported volumetric soil } \\
\text { water at field capacity }\left(\mathrm{m}^{3} \mathrm{~m}^{-3}\right)\end{array}$ & 0.32 \\
\hline $\begin{array}{l}\text { Reported volumetric soil water at } \\
\text { permanent wilting point }\left(\mathrm{m}^{3} \mathrm{~m}^{-3}\right)\end{array}$ & $\begin{array}{c}\text { Lower limit of plant available } \\
\text { water }=0.12-0.16\end{array}$ \\
\hline $\begin{array}{l}\text { Rain: Amount (mm) and } \\
\text { number of events: Start to end }\end{array}$ & $26.2,12$ \\
\hline $\begin{array}{l}\text { Irrigation: Amount (mm) and } \\
\text { number of events: Start to end }\end{array}$ & $215.3,4$ \\
\hline Crop & Start of data period is after the \\
\hline Planting date & harvest of garden peas and end of \\
\hline Emergence data & period is before planting of winter \\
\hline $\begin{array}{l}\text { Leaf area index (LAI) at } \\
\text { data end }\end{array}$ & \\
\hline Other measured LAI & \\
\hline
\end{tabular}

presented graphically for visual analysis and compared statistically.

These three series of simulations represent an array of possible methods for choosing the soil data that one might use, and the comparison of the results from the three series offers an assessment of the possible impact on the estimation caused by differences between the methods. Prior to describing the differentiation of the soil parameter selections for these three series of simulations, a short discussion of Stage 3 evaporation and the cracking nature of the soils is appropriate.

The FAO-56 model presented in Allen et al. (1998) allowed evaporation to occur in a two-stage process similar in appearance to the empirical model presented by Ritchie (1972). In the FAO-56 model, the relative evaporation rate $\left(K_{r}=E / E_{p}\right.$, where $E_{p}=$ potential evaporation rate for wet soil) decreases linearly with increasing cumulative evaporation during Stage 2. In this study, a third stage of evaporation is represented by changing the slope of the falling rate of Stage 2. Stage 3 evaporation is associated with a slow and steady vapor transfer rate between moist deep soil and the dry air above, or with soil cracking that exposes deeper soil to the surface evaporation potential. The option for Stage 3 evaporation was added to the FAO- 56 model by Allen (1998) to simulate deeply cracking soils in the Imperial Valley of California. The three-stage FAO-56 style model was described by Allen et al. (2005). The values for $\mathrm{TEW}_{3}$ and $K_{r 2}$, the value for $K_{r}$
Table 6. Summary for Data Set 2: Sandy Clay Loam ${ }^{\mathrm{a}}$

\begin{tabular}{|c|c|}
\hline Parameter & Parameter values for data set \\
\hline Data set number & 7 \\
\hline Source & Farahani and Bausch (1995) \\
\hline Location & Fort Collins, Colo. \\
\hline Soil & Sandy clay loam \\
\hline Supporting weather data & CoAgMet Sta. Ftc03-Fort Collins \\
\hline $\begin{array}{l}\text { Evaporation } \\
\text { measurement method }\end{array}$ & $\begin{array}{c}\text { Bowen ratio equipment }{ }^{\mathrm{b}}: E T \\
\text { Measurements are for } 7 \text { a.m. to } 7 \text { p.m. }\end{array}$ \\
\hline & $\begin{array}{l}\text { Values were adjusted to account for } \\
24 \mathrm{~h} \text { of evaporation by } \\
\text { multiplying measured evaporation } \\
\text { by Rs- } 24 \mathrm{~h} / \text { Rs- }^{-} 7 \text { a.m. }-7 \text { p.m. }\end{array}$ \\
\hline Start date & May 15,1993 \\
\hline Date end & June 8, 1993 \\
\hline Total days & 25 \\
\hline $\begin{array}{l}\text { Reported preirrigation } \\
\text { volumetric soil water }\end{array}$ & 0.28 \\
\hline $\begin{array}{l}\text { Reported volumetric soil } \\
\text { water at field capacity }\end{array}$ & 0.34 \\
\hline $\begin{array}{l}\text { Reported volumetric soil water } \\
\text { at permanent wilting point }\end{array}$ & 0.265 \\
\hline $\begin{array}{l}\text { Rain: Amount }(\mathrm{mm}) \text { and number } \\
\text { of events: Start to end }\end{array}$ & $56.1,10$ \\
\hline Irrigation: Amount (mm) & none \\
\hline
\end{tabular}

Field corn

Crop

Planting date

April 28, 1993

Emergence date

Leaf area index (LAI) at data

end $^{\mathrm{c}}$

Other measured LAI

May 12, 1993

0.16

${ }^{\mathrm{a}}$ Farahani stated that the laboratory evaluation of the soil from the study location classified it as a sandy clay loam. The maps identify the area as a Kim loam.

${ }^{\mathrm{b}} 12 \mathrm{~h}$ ET measured with Bowen Ratio equipment was calibrated in Bushland, Tex. against lysimeter measurements.

${ }^{\mathrm{c}} E$ and $T$ data as partitioned in Ritchie (1972) indicated that loss from transpiration is very small when the leaf area index is 0.15 or less.

at the start of Stage 3, were based on unpublished work presented in the Imperial Irrigation District Water Use Assessment for the Years 1987-1996. For this research, Stage 3 evaporation was used if specific soils were identified as cracking soils in the USDANRCS Soil Survey Division Official Soil Series Descriptions. The soil parameter selection process for each of the three series of simulations follows.

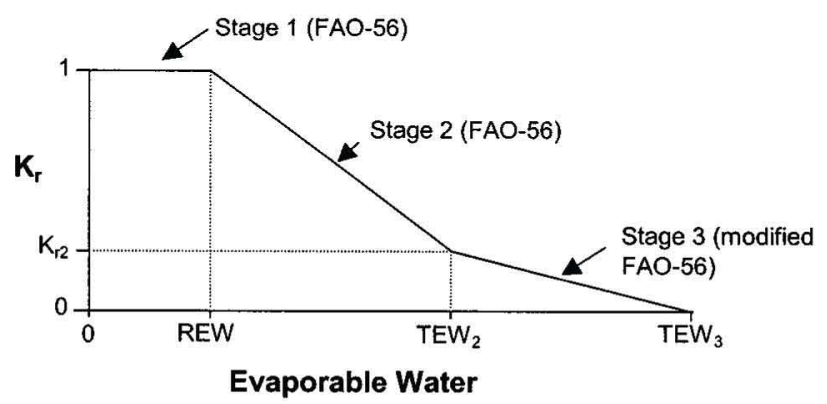

Fig. 1. Three stage soil evaporation process 
Evaporation parameters

Soil water characteristics

\begin{tabular}{|c|c|c|c|c|c|}
\hline $\begin{array}{l}\text { Soil type } \\
\text { (USA Soil } \\
\text { Texture } \\
\text { Classification) }\end{array}$ & $\begin{array}{c}\theta_{\mathrm{FC}}{ }^{\mathrm{a}} \\
\left(\mathrm{m}^{3} \mathrm{~m}^{-3}\right)\end{array}$ & $\begin{array}{c}\theta_{\mathrm{WP}}^{\mathrm{b}} \\
\left(\mathrm{m}^{3} \mathrm{~m}^{-3}\right)\end{array}$ & $\begin{array}{l}{ }_{\mathrm{FC}}-\theta_{\mathrm{WP}} \\
\left(\mathrm{m}^{3} \mathrm{~m}^{-3}\right)\end{array}$ & $\begin{array}{l}\text { Stage } 1 \\
\text { REW } \\
(\mathrm{mm})\end{array}$ & $\begin{array}{c}\text { Stages } 1 \text { and } 2 \\
\text { TEW }^{\mathrm{c}} \\
\left(Z_{e}^{\mathrm{d}}=0.10 \mathrm{~m}\right) \\
(\mathrm{mm})\end{array}$ \\
\hline Sand & $0.07-0.17$ & $0.02-0.07$ & $0.05-0.11$ & $2-7$ & $6-12$ \\
\hline Loamy sand & $0.11-0.19$ & $0.03-0.10$ & $0.06-0.12$ & $4-8$ & $9-14$ \\
\hline Sandy loam & $0.18-0.28$ & $0.06-0.16$ & $0.11-0.15$ & $6-10$ & $15-20$ \\
\hline Loam & $0.20-0.30$ & $0.07-0.17$ & $0.13-0.18$ & $8-10$ & $16-22$ \\
\hline Silt loam & $0.22-0.36$ & $0.09-0.21$ & $0.13-0.19$ & $8-11$ & $18-25$ \\
\hline Silt & $0.28-0.36$ & $0.12-0.22$ & $0.16-0.20$ & $8-11$ & $22-26$ \\
\hline Silt clay loam & $0.30-0.37$ & $0.17-0.24$ & $0.13-0.18$ & $8-11$ & $22-27$ \\
\hline Silty clay & $0.30-0.42$ & $0.17-0.29$ & $0.13-0.19$ & $8-12$ & $22-28$ \\
\hline Clay & $0.32-0.40$ & $0.20-0.24$ & $0.12-0.20$ & $8-12$ & $22-29$ \\
\hline
\end{tabular}

\section{Simulation Series 1: General Soil Parameters from FAO-56 as Used in the CALFED/ARI Evaporation Study}

The CALFED/ARI Evaporation Study (Burt et al. 2002) used general values for the REW and $\mathrm{TEW}_{2}$ soil parameters as recommended in FAO-56 Table 19 (see Table 7 of this paper). The Houston black clay was simulated using average REW and TEW values from Table 7 for clay. The clay loam, silt loam, and sandy clay loam soils were grouped together and were represented by typical REW and TEW values from Table 7 for a silt texture. Although Table 19 of FAO-56 contains characteristics of a silt loam, it was felt that the REW and TEW values for a silt more closely matched the mix of the CALFED/ARI Evaporation Study soils. The $Z_{e}$ parameter was set at $0.1 \mathrm{~m}$.

The Portneuf silt loam soil at Kimberly, Id., which was not identified as having cracking tendencies, was modeled using a third stage of evaporation during the Series 1 simulation since three-stage evaporation was used in all simulations of silt loam soils in the CALFED/ARI Evaporation Study. The third stage, and associated $\mathrm{TEW}_{3}$, provided better estimates than did a twostage simulation for the Portneuf silt loam soil when a $Z_{e}=0.1$

Table 8. Series 1 Simulation Soil Parameter Values. ${ }^{a}$ These Follow the Soil Groupings Used in the CALFED/ARI Evaporation Study and Were Used in the Comparison between Measured and FAO-56 Simulated Bare Soil Evaporation.

\begin{tabular}{|c|c|c|c|c|c|}
\hline & $\begin{array}{l}\text { Houston black } \\
\text { clay }\end{array}$ & Yolo clay loam & $\begin{array}{l}\text { Pullman clay } \\
\text { loam }\end{array}$ & $\begin{array}{l}\text { Portneuf silt } \\
\text { loam }\end{array}$ & $\begin{array}{l}\text { Kim loam/sandy } \\
\text { clay loam }\end{array}$ \\
\hline Source & Ritchie (1972) & $\begin{array}{l}\text { Parlange et al. } \\
\text { (1992) }\end{array}$ & $\begin{array}{l}\text { Howell et al. } \\
\text { (1995) }\end{array}$ & $\begin{array}{l}\text { Wright (personal } \\
\text { communication, 2001) }\end{array}$ & $\begin{array}{l}\text { Farahani and Bausch } \\
\qquad(1995)\end{array}$ \\
\hline Stage 1 REW (mm) & 10 & 9 & 9 & 9 & 9 \\
\hline Stages 1 and $2 \mathrm{TEW}_{2}(\mathrm{~mm})$ & 26 & 24 & 24 & 24 & 24 \\
\hline Stages 1,2 , and $3 \mathrm{TEW}_{3}(\mathrm{~mm})^{\mathrm{b}}$ & 50 & - & 45 & 40 & - \\
\hline$K_{r 2}$ : Evaporation Coefficient at end of Stage $2^{\mathrm{b}}$ & 0.2 & - & 0.2 & 0.2 & - \\
\hline $\begin{array}{l}Z_{e} \text { or the effective depth of soil } \\
\text { evaporation layer }(\mathrm{m})^{\mathrm{c}}\end{array}$ & 0.1 & 0.1 & 0.1 & 0.1 & 0.1 \\
\hline Cracking nature of simulated soil ${ }^{\mathrm{d}}$ & Yes & No & Yes & $\mathrm{No}^{\mathrm{d}}$ & No \\
\hline
\end{tabular}

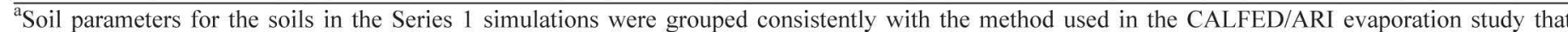
estimated evaporation from California agricultural lands. In that study the clay loam, silt loam, and sandy clay loam soils were grouped together and the Stage 1 and Stage 2 soil parameters for this group were represented by the parameters for an average silt soil as identified in Table 19 of Allen et al. (1998). Note that $Z_{e}$ in the CALFED/ARI Evaporation Study was set at 0.1 for all soils.

${ }^{\mathrm{b}}$ Stage 3 evaporation parameters for the three-Stage FAO-56 model were based on information from the report: Water Study Team. Imperial Irrigation District Water Use Assessment for the years 1987-1996 (1998). Received via Freedom of Information Act.

${ }^{\mathrm{c}}$ FAO-56 recommends using values for $Z_{e}$ between 0.1 and $0.15 \mathrm{~m} . Z_{e}$ was set to $0.1 \mathrm{~m}$ during Simulation Series 1 and 2.

${ }^{\mathrm{d}}$ In the Series 1 simulations, the cracking soil designations match the USDA-NRCS Soil Survey Division Official Soil Series Description designations of this property for the actual soils from the five locations. However, some silt loam soils in the CALFED/ARI evaporation study were modeled using a third stage of evaporation. For the Series 1 simulations, the Portneuf silt loam at Kimberly was modeled better using a third stage of evaporation than without when $Z_{e}=0.1 \mathrm{~m}$ was used, and was modeled in this manner to represent those California silt loam soils where three stages of evaporation were used in the CALFED/ARI evaporation study. 
Table 9. Series 2 Simulation Soil Parameter Values

\begin{tabular}{|c|c|c|c|c|c|}
\hline & $\begin{array}{l}\text { Houston black } \\
\text { clay }\end{array}$ & Yolo clay loam & $\begin{array}{l}\text { Pullman clay } \\
\text { loam }\end{array}$ & $\begin{array}{l}\text { Portneuf silt } \\
\text { loam }\end{array}$ & $\begin{array}{l}\text { Kim loam/sandy } \\
\text { clay loam }\end{array}$ \\
\hline Source & Ritchie (1972) & $\begin{array}{l}\text { Parlange et al. } \\
\qquad(1992)\end{array}$ & Howell et al. (1995) & $\begin{array}{l}\text { Wright (personal } \\
\text { communication, 2001) }\end{array}$ & $\begin{array}{c}\text { Farahani and Bausch } \\
\text { (1995) }\end{array}$ \\
\hline $\begin{array}{l}\text { Specific soil texture from } \\
\text { evaporation experiment location }\end{array}$ & $\begin{array}{l}\text { Clay; } 55 \% \text { fine } \\
\text { montmorillinite } \\
\quad \text { clay }\end{array}$ & Clay loam & Clay loam & Silt loam & $\begin{array}{l}\text { Loam, but sandy clay } \\
\text { loam by lab analysis } \\
\text { of soil at site }\end{array}$ \\
\hline Stage 1 REW (mm) & - & 7 & 8 & 8 & 8 \\
\hline Stage 1 and $2 \mathrm{TEW}_{2}(\mathrm{~mm})^{\mathrm{a}}$ & 一 & 18.7 & 23 & 37.5 & 20.8 \\
\hline Stages 1,2 , and $3 \mathrm{TEW}_{3}(\mathrm{~mm})^{\mathrm{b}}$ & - & - & 45 & - & - \\
\hline Evaporation Coefficient at end of Stage $2^{b}$ & - & - & 0.2 & - & - \\
\hline $\begin{array}{l}Z_{e} \text { or the effective depth of soil } \\
\text { evaporation layer for Stage } 2 \\
\text { evaporation }(\mathrm{m})^{\mathrm{a}}\end{array}$ & - & 0.1 & 0.1 & 0.15 & 0.1 \\
\hline Cracking nature of observed soil ${ }^{\mathrm{c}}$ & Yes & No & Yes & No & No \\
\hline
\end{tabular}

${ }^{\mathrm{a}}$ The TEW for the Series 2 simulations were computed using Eq. 73 from Allen et al. (1998): TEW $=1,000(\mathrm{FC}-0.5 \mathrm{WP}) Z_{e}$, where field capacity (FC) and wilting point (WP) were reported by the scientist and are listed in Table 1. As with the Series 1 simulations, all soils in the Series 2 simulations were modeled with a $Z_{e}=0.10 \mathrm{~m}$ except the Portneuf silt loam, where $Z_{e}=0.15 \mathrm{~m}$ as recommended Allen (personal communication, 2001) and Wright (personal communication, 2001). REW values for the Series 2 simulations were approximated from the reported FC and WP values. Scientist reported soil parameter values were not available for the Houston black clay. Therefore this soil was not simulated during Series 2.

${ }^{\mathrm{b}}$ Stage 3 evaporation parameters for the extended FAO-56 model were based on information from the report: Water Study Team. Imperial Irrigation District Water Use Assessment for the Years 1987-1996 (1998). Received via Freedom of Information Act.

${ }^{\mathrm{c}}$ Note that the cracking tendencies of the soils for the Series 2 and Series 3 simulations match the USDA-NRCS Soil Survey Division Official Soil Series Description designations of this property for the actual soils from the five locations. The change from cracking to noncracking designation for Portneuf silt loam was strengthened by statements from the local scientists: Allen (personal communication, 2001) stated that this soil seems to be better modeled without cracking tendencies and, from personal observations, Wright (personal communication, 2001) stated that although the portion of a Portneuf silt loam furrow that is saturated usually does crack on drying, the cracking is typically only about $0.05 \mathrm{~m}$ deep. The surface soil that is wetted by soaking in between the furrows usually does not crack on drying.

was used. A larger value for $Z_{e}$ and a two stage simulation was used for the Portneuf soil during Series 2. Table 8 shows the specific soil parameters used in the Series 1 simulations.

\section{Simulation Series 2: Scientist-Reported Soil Parameters}

For this series of simulations, the FAO-56 Model used REW and $\mathrm{TEW}_{2}$ soil parameters that were developed from detailed soils data provided by the scientists that conducted the specific field evaporation studies. Specific soils data for the Houston black clay were not available. The $Z_{e}$ parameter for the Portneuf silt loam was changed to $0.15 \mathrm{~m}$, as recommended by Allen (personal communication, 2001) and Wright (personal communication, 2001). For the other soils, $Z_{e}$ was left at $0.1 \mathrm{~m}$. The Portneuf silt loam soil simulation was run without Stage 3 evaporation in the Series 2 simulations. Table 9 shows the specific soil parameters used in the Series 2 simulations.

\section{Simulation Series 3: Best-Fit Soil Parameters}

Simulation Series 3 modified soil parameters from the Series 2 simulations. REW, TEW $2, \mathrm{TEW}_{3}$, and $K_{r 2}$ evaporation coefficients were altered manually to obtain the best fit between the

Table 10. Simulation series 3 soil Parameter Values Altered to Produce the Best Comparison Between Measured and FAO-56-style Simulated Evaporation.

\begin{tabular}{|c|c|c|c|c|c|}
\hline & $\begin{array}{l}\text { Houston black } \\
\text { clay }\end{array}$ & Yolo clay loam & $\begin{array}{l}\text { Pullman clay } \\
\text { loam }\end{array}$ & $\begin{array}{l}\text { Portneuf silt } \\
\text { loam }\end{array}$ & $\begin{array}{l}\text { Kim loam/sandy } \\
\text { clay loam }\end{array}$ \\
\hline Source & $\begin{array}{l}\text { Ricthie } \\
(1972)\end{array}$ & $\begin{array}{l}\text { Parlange et al. } \\
\text { (1992) }\end{array}$ & $\begin{array}{l}\text { Howell et al. } \\
\text { (1995) }\end{array}$ & $\begin{array}{l}\text { Wright personal } \\
\text { communication, (2001) }\end{array}$ & $\begin{array}{l}\text { Farahani and Bausch } \\
\qquad(1995)\end{array}$ \\
\hline Stage 1 REW (mm) & 7 & 2 & 7 & 13 & 10 \\
\hline Stages 1 and $2 \mathrm{TEW}_{2}(\mathrm{~mm})^{\mathrm{a}}$ & 30 & 6 & 22 & 40 & 25 \\
\hline Stages 1,2 , and $3 \mathrm{TEW}_{3}(\mathrm{~mm})^{\mathrm{b}}$ & 50 & 18 & 45 & - & - \\
\hline Evaporation Coefficient at end of Stage $2^{b}$ & 0.3 & 0.35 & 0.2 & - & - \\
\hline $\begin{array}{l}Z_{e} \text { or the effective depth of soil } \\
\text { evaporation layer }(\mathrm{m})^{\mathrm{a}}\end{array}$ & 0.115 & 0.032 & 0.096 & 0.16 & 0.12 \\
\hline Cracking nature of simulated soil ${ }^{\mathrm{c}}$ & Yes & No & Yes & No & No \\
\hline
\end{tabular}



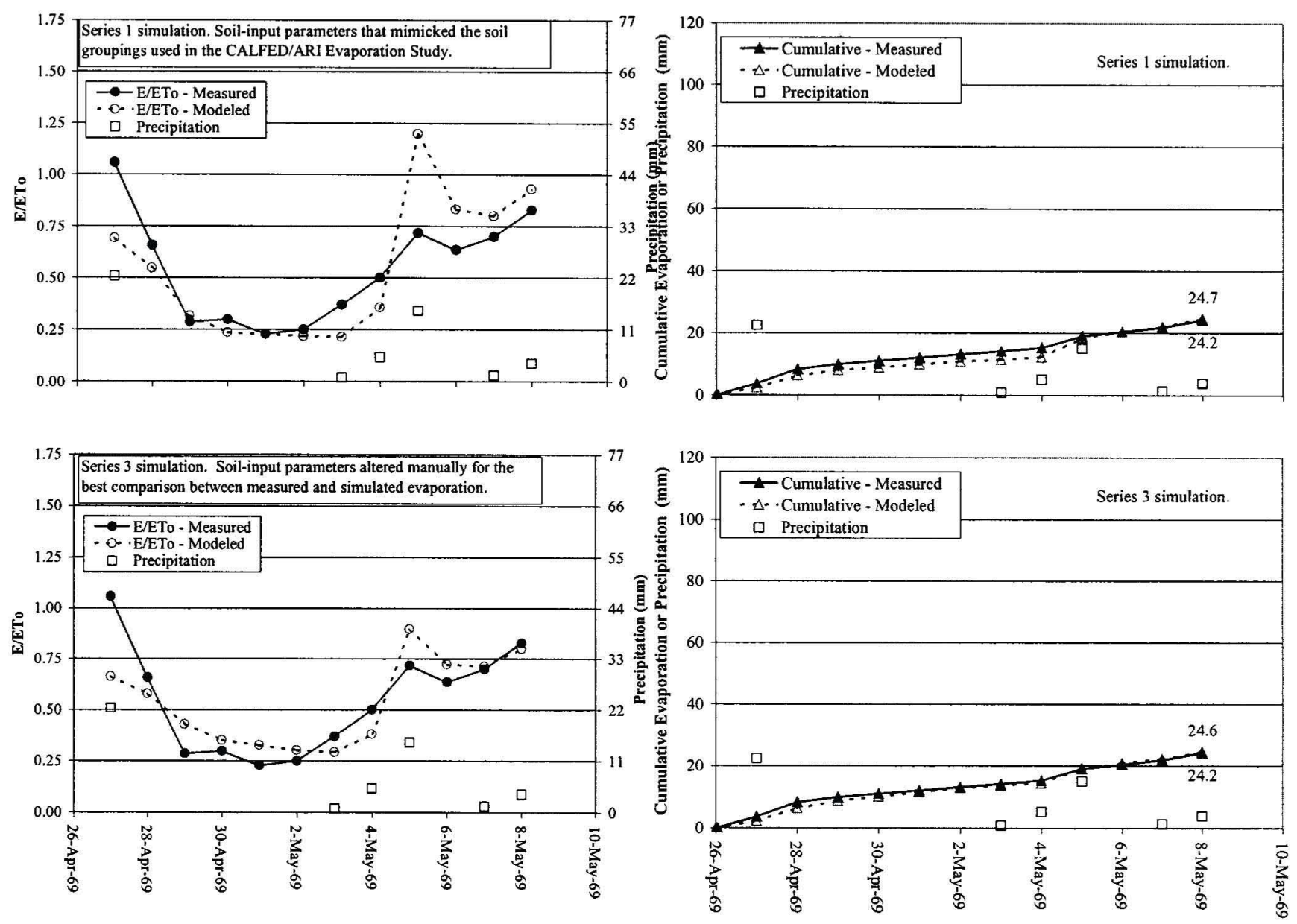

Fig. 2. Comparison of daily bare soil E/ETo ratios and of cumulative bare soil evaporation for lysimeter measurements in 1990 at Temple, Tex.- Houston black clay - reported by Ritchie (1972) and FAO-56 model results. Simulation results for two variations on the soil parameter definitions. Scientist reported soil parameter values were not available for this soil. Therefore it was not simulated during Series 2 .

measured and simulated evaporation events. During Simulation Series 3, the Yolo clay loam was altered to include Stage 3 evaporation. The $Z_{e}$ parameters were modified from those used in the Series 2 simulations to create values for $\mathrm{TEW}_{2}$ as shown in Table 10. Table 10 summarizes the specific soil parameters used in the Series 3 simulation.

\section{Results and Discussion}

The figures in this section display the measured and simulated $E$ /ETo versus time, and cumulative evaporation versus time, for five of the seven bare soil evaporation data sets used to evaluate the model. The results from these five data sets demonstrate key points learned from this evaluation. Each figure includes measured and simulation comparisons for the three variations (Series 1,2 , and 3 ) used for defining the soil parameters.

\section{General Observations about the Figures of EIETo and Cumulative $E$}

1. The measured and simulated $E /$ ETo and cumulative bare soil evaporation trends (Figs. 2-6) were similar among the three simulation series that used different approaches to define soil parameters. This indicates that the FAO-56 evaporation model is generally valid for predicting evaporation from bare soil and that the general soil values published in FAO-56 are sufficient for general prediction work.

2. The similarity between predicted and measured evaporation values offers confidence as to the capability of the two-stage and three-stage FAO-56 model to provide good prediction of bare soil evaporation when there is sound weather data.

3. Following large precipitation or irrigation events, the FAO-56 simulated ratios of $E /$ ETo were similar to measured ratios of E/ETo (Figs. 2-6). Maximum measured E/ETo often exceeded 1.2, which contrasts with findings by Snyder et al. (2000), who found that maximum E/ETo measurements following soil wetting ranged from 0.8 to 1.0 in Imperial Valley, Calif.

4. The response of E/ETo to small precipitation or irrigation events occurring several days after a large irrigation event as simulated by the FAO-56 model tended to be smoother and of lower magnitude than the measured $E / E T o$ response (Figs. 2-6). This is due to the dampening caused by the water balance conducted for the entire surface soil layer (of depth $Z_{e}$ ) in the FAO-56 model, so that small wetting events increase the average water content of the entire layer by a small amount and consequently the predicted ratio $E /$ ETo may not change significantly. In reality, small events will rehydrate the skin of the soil surface and will generally shift 

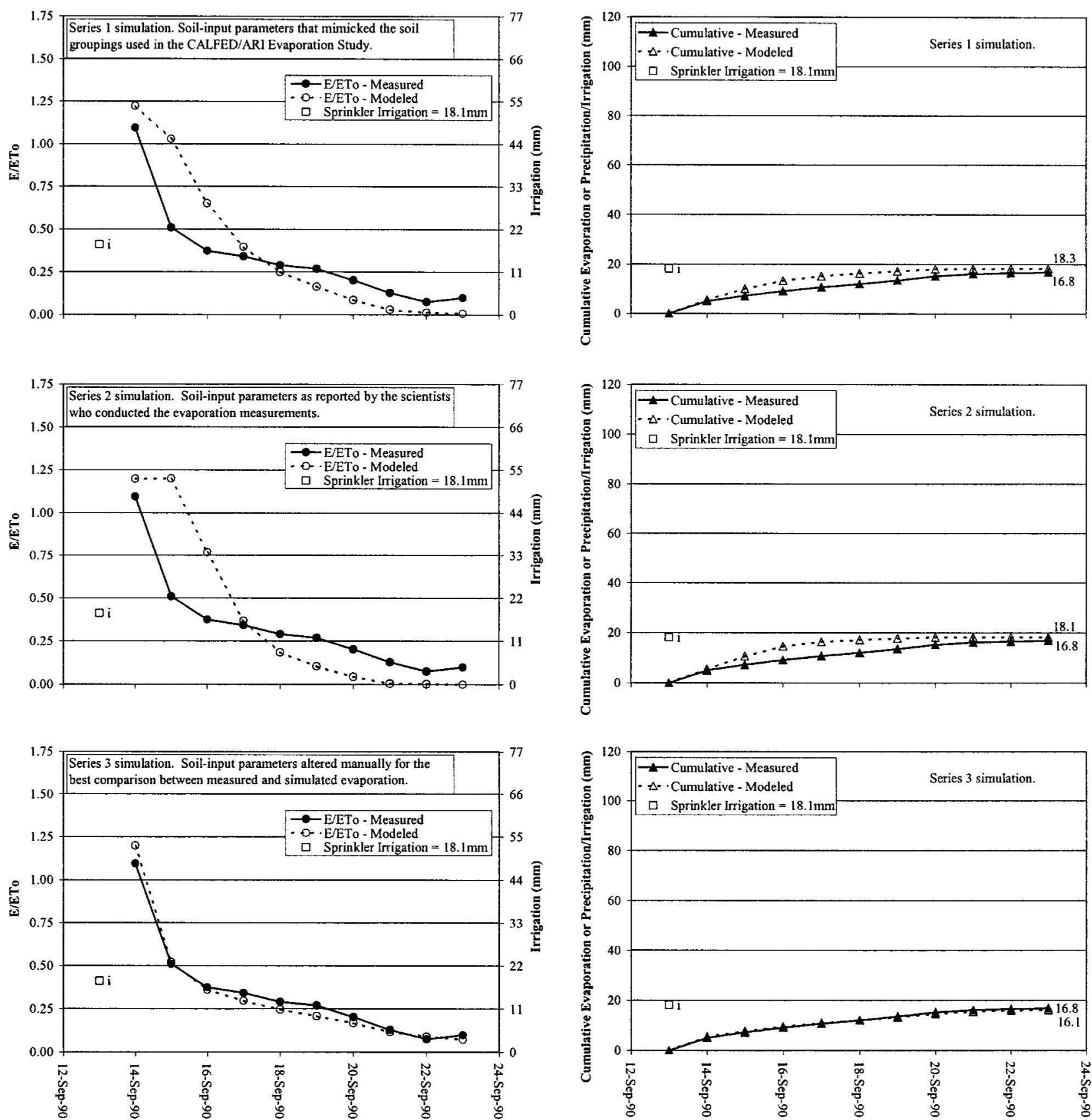

Fig. 3. Comparison of daily bare soil E/ETo ratios and of cumulative bare soil evaporation for lysimeter measurements in 1990 at Davis, Calif.-Yolo clay loam - reported by Parlange et al. (1992) and FAO-56 model results. Simulation results for three variations on the soil parameter definitions.

the evaporation process temporarily into Stage 1 drying. Allen et al. (2005) have expanded the FAO-56 method to conduct two separate water balances of the surface soil layer to account for skin wetting. Their expansion of the method was not tested in this study.

5. Occasionally, the upper limit on the evaporation and transpiration component $\left(K_{c \max }=1.20\right)$ in the Modified FAO-56 model was reached and even exceeded (Figs. 2-6). It should be noted that $K_{c \max }$ is intended for cropped surfaces, but in the CALFED/ARI Evaporation Study this limit was included in the bare soil evaporation as well. The value of 1.20 is to account for impacts of lower albedo of wet soil relative to grass, coupled with heat storage in the soil surface layer prior to wetting (Allen et al. 1998). The impact of allowing $K_{c \max }$ to limit the rate of bare soil evaporation appears to be minimal since it was only occasionally exceeded by measured data and, over time, the simulated cumulative evaporation was very similar to the measured value for all three series of simulations (Figs. 2-6).

\section{General Observations about the Statistical Evaluation of the Bare Soil Evaporation Simulations}

There are several possibilities that could be used as a basic evaluation of how well the two-stage FAO-56 model and enhancement to a three-stage model performed in simulating soil evaporation. The method that seemed most appropriate was to compare the evaporation weighted average percent difference between the 

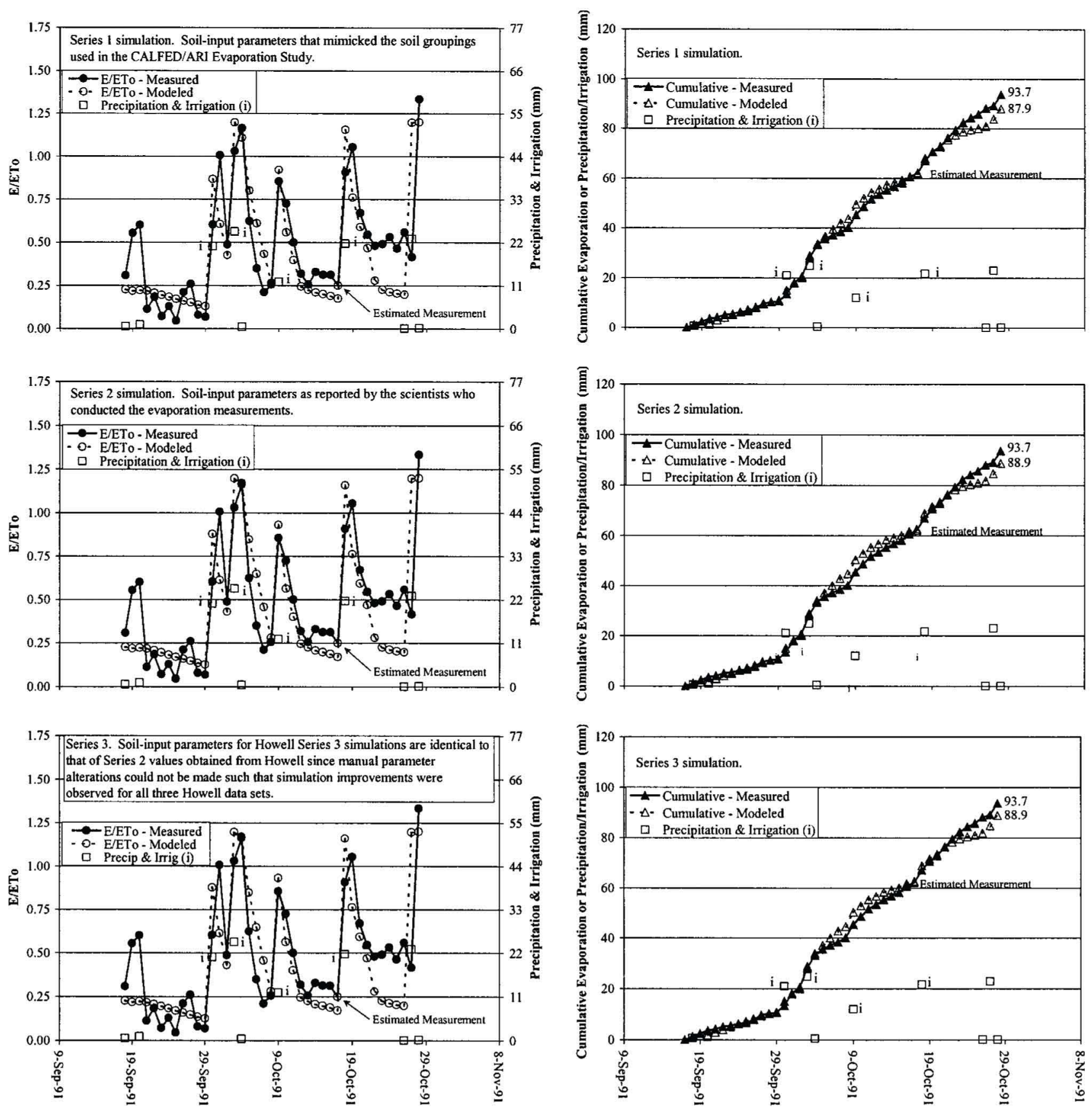

Fig. 4. Comparison of daily bare soil E/ETo ratios and of cumulative bare soil evaporation for lysimeter measurements in 1991 at Bushland, Tex.-Pullman clay loam—reported by Howell et al. (1995) and three-stage FAO-56 model results. Simulation results are for three variations on the soil parameter definitions.

measured and the simulated cumulative bare soil evaporation. The evaporation weighted average was a straightforward method of minimizing bias that could be introduced by the variation in the time of year, the geographical location, and length of evaluation period for the seven data sets.

The evaporation weighted average percent difference between the measured and FAO-56 simulated cumulative evaporation was negative for all three methods of defining the simulation parameters for all soils (Tables 11-13). As one might expect, the general method for defining the soil parameters (Series 1 simulations) resulted in more average evaporation weighted error than when the scientist-reported (Series 2) or best-fitted (Series 3) soil parameters were used: $-7.3,-4.2$, and $-3.1 \%$, respectively, when the Ritchie data set is not included.

\section{Specific Findings from This Evaluation of Soil Water Evaporation Predicted by the Two- or Three-Stage FAO-56 Model}

Specific findings from this evaluation of soil water evaporation predicted by the two- or three-stage FAO-56 model are

1. The FAO-56 style soil water evaporation model, patterned 

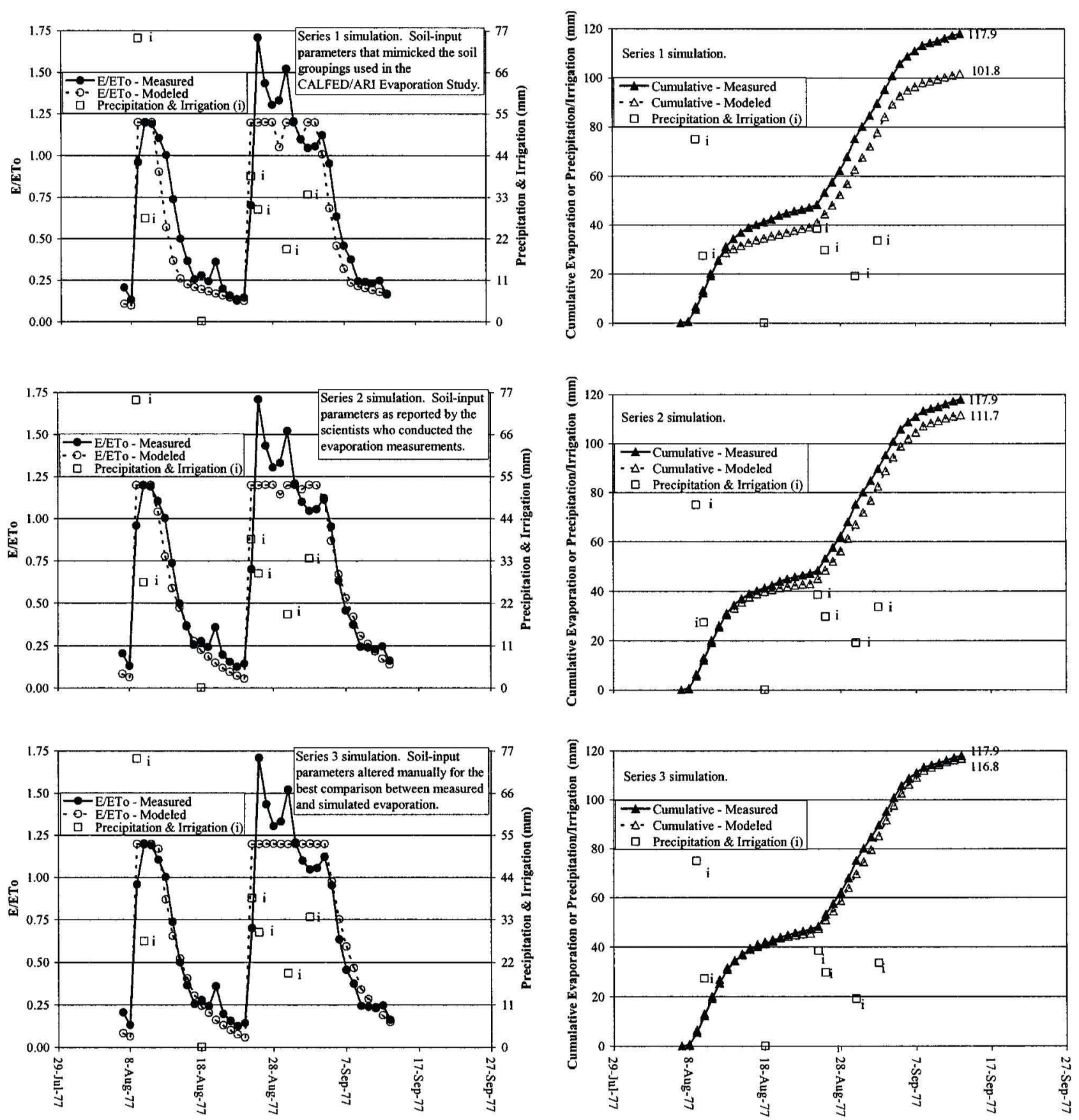

Fig. 5. Comparison of daily bare soil E/ETo ratios and of cumulative bare soil evaporation. Lysimeter measured (in 1977 at Kimberly, Id.-Portneuf silt loam-reported by Wright personal communication, 2001) and FAO-56 model results. Simulation results are for three variations on the soil parameter definitions.

after Ritchie (1972), provided a good physical structure for simulating evaporation from bare soil. The use of a daily soil water balance and the use of two or three stages of drying in the model appears to be sound. There is a tendency for a small to modest improvement in model results when scientist-reported soil parameters (Series 2) are used in simulations, rather than general parameters from FAO-56 whose values are based on general textural classes (Series 1).

Specifically, the improvement in the straight percent difference between the measured and modeled cumulative bare soil evaporation ranged from 1 to $2 \%$ for 4 of the 6 comparable data sets.
Results were worse for Series 2 as compared to Series 1 for a fifth data set [the 1992 lysimeter data from Howell et al. (1995) found in Tables 11 and 12].

The sixth Series 2 simulation [using Wright (personal communication 2001) data] that had scientist-reported soil data for the Portneuf silt loam soil in Kimberly, Id. resulted in the most significant improvement over the Series 1 simulation, by increasing the depth of the evaporation zone $\left(Z_{e}\right)$ from $0.1 \mathrm{~m}$ to the reported value of $0.15 \mathrm{~m}$ and using a two-stage process rather than threestages. The Series 2 simulation brought the cumulative evaporation $8.4 \%$ closer to the measured cumulative value (Fig. 5 and 

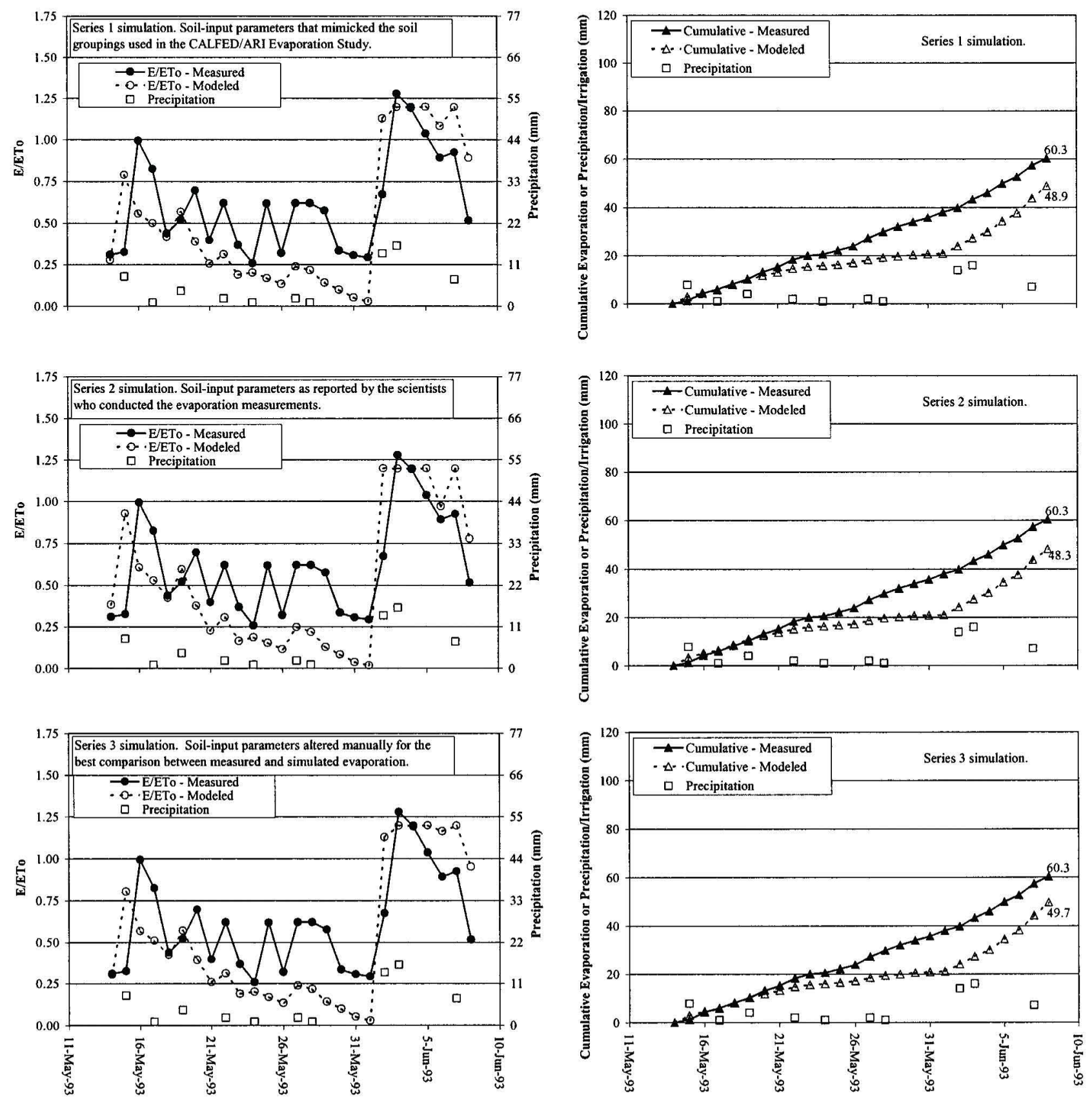

Fig. 6. Comparison of daily bare soil E/ETo ratios and of cumulative bare soil evaporation for Bowen Ratio measurements in 1999 at Fort Collins, Colo.—sandy clay loam—reported by Farahani and Bausch (1995) and FAO-56 model results. Simulation results for three variations on the soil parameter definitions.

Tables 11 and 12). This improvement occurred even though the total evaporative water (TEW) for the two series was essentially the same $\left(\mathrm{TEW}_{3}\right.$ in Series 1 was $40 \mathrm{~mm}$ and $\mathrm{TEW}_{2}$ in Series 2 was $38 \mathrm{~mm}$ ). The two-stage series allowed water to be depleted more quickly between wetting events.

This information indicates that if a bare soil evaporation simulation using the FAO-56 model is conducted for an individual soil, it is generally best to use scientist-reported soil parameters if they are available. However, when a bare soil evaporation simulation is conducted for many soil types simultaneously, for example, in computing water consumption for a large area, the expedience of using generalized soil parameters will likely result in only a modest reduction in the overall prediction accuracy. The best value for $Z_{e}$, the soil depth parameter for the FAO-56 model, is not well defined for specific soils, but a general value of $0.1 \mathrm{~m}$ worked well for three of the five soils in this evaluation. The Portneuf and Colorado soils required a $0.15 \mathrm{~m}$ depth for accurate simulation with the two-stage evaporation model.

2. To obtain the best fit between the measured and simulated bare soil evaporation (Series 3, Table 13), the REW parameter (Table 10) was altered to a value outside of the typical range for this parameter, as listed in Table 7. For example, the best-fit REW for the Yolo clay loam data set was $2 \mathrm{~mm}$, although the typical REW range for a silt loam soil listed in Table 7 is $8-11 \mathrm{~mm}$. (Note that Table 7 does not list clay loam. Therefore average silt loam parameters were used to define the clay loam soils in the Series 1 simulations.) Further, the best fit required a third stage of evaporation for the 
Table 11. Measurements of Bare Soil Evaporation Compared to FAO-56 Simulated Bare Soil Evaporation. Simulation Series 1.

\begin{tabular}{|c|c|c|c|c|c|c|c|}
\hline & $\begin{array}{l}\text { Ritchie } \\
(1972)\end{array}$ & $\begin{array}{l}\text { Parlange et al. } \\
\qquad(1992)\end{array}$ & \multicolumn{3}{|c|}{ Howell et al. (1995) } & $\begin{array}{l}\text { Wright (personal } \\
\text { communication, 2001) }\end{array}$ & $\begin{array}{l}\text { Farahani and } \\
\text { Bausch (1995) }\end{array}$ \\
\hline Soil type & Clay & Clay loam & \multicolumn{3}{|c|}{ Clay loam } & Silt loam & $\begin{array}{l}\text { Sandy Clay } \\
\text { loam }\end{array}$ \\
\hline Year measurements were collected & 1969 & 1990 & 1989 & 1991 & 1992 & 1977 & 1993 \\
\hline Measurement method & Lysimeter & Lysimeter & \multicolumn{3}{|c|}{ Lysimeter } & Lysimeter & Bowen ratio \\
\hline $\begin{array}{l}\text { Number of days from start to end of evaluated } \\
\text { period }\end{array}$ & 12 & 10 & 31 & 41 & 40 & 37 & 25 \\
\hline Rain or irrigation during period (mm) & 48.4 & 18.1 & 74.0 & 104.8 & 95.7 & 223.8 & 56.1 \\
\hline Measured cumulative bare soil evaporation (mm) & 24.2 & 16.8 & 52.8 & 93.7 & 81.2 & 117.9 & 60.3 \\
\hline $\begin{array}{l}\text { Modified FAO-56 modeled cumulative bare soil } \\
\text { evaporation }(\mathrm{mm})\end{array}$ & 24.7 & 18.3 & 51.5 & 87.9 & 84.4 & 101.8 & 48.1 \\
\hline $\begin{array}{l}\text { Percent difference between measured and modeled } \\
\text { cumulative } E(\%)\end{array}$ & 2.1 & 8.9 & -2.4 & -6.1 & 3.9 & -13.7 & -20.2 \\
\hline \multicolumn{6}{|c|}{$\begin{array}{l}\text { Evaporation-weighted average percent difference between measured and modeled cumulative bare soil } \\
\text { evaporation }(\%)\end{array}$} & $\begin{array}{c}\text { Without } \\
\text { Ritchie } \\
-7.3\end{array}$ & $\begin{array}{l}\text { All data sets } \\
-6.3\end{array}$ \\
\hline
\end{tabular}

Table 12. Measurements of Bare Soil Evaporation Compared to FAO 56 Simulated Bare Soil Evaporation. Simulation Series 2.

\begin{tabular}{|c|c|c|c|c|c|c|c|}
\hline \multirow[b]{2}{*}{ Measured cumulative bare soil evaporation (mm) } & \multirow{2}{*}{$\begin{array}{c}\text { Ritchie } \\
(1972)\end{array}$} & \multirow{2}{*}{$\begin{array}{c}\text { Parlange et al. } \\
\text { (1992) } \\
16.8\end{array}$} & \multicolumn{3}{|c|}{$\begin{array}{l}\text { Howell et al. } \\
\quad(1995)\end{array}$} & \multirow{2}{*}{$\begin{array}{c}\begin{array}{c}\text { Wright } \\
\text { (personal communication, 2001) }\end{array} \\
117.9\end{array}$} & \multirow{2}{*}{$\begin{array}{c}\text { Farahani and } \\
\text { Bausch (1995) }\end{array}$} \\
\hline & & & 52.8 & 93.7 & 81.2 & & \\
\hline $\begin{array}{l}\text { Modified FAO-56 modeled cumulative bare soil } \\
\text { evaporation }(\mathrm{mm})\end{array}$ & - & 18.1 & 52.5 & 88.9 & 85.6 & 111.7 & 48.3 \\
\hline \multirow{2}{*}{$\begin{array}{l}\text { Percent difference between measured and modeled } \\
\text { cumulative } E(\%)\end{array}$} & - & 7.9 & -0.6 & -5.1 & 5.4 & -5.3 & -19.9 \\
\hline & & & & & & $\begin{array}{l}\text { Without } \\
\text { Ritchie }\end{array}$ & - \\
\hline \multicolumn{6}{|c|}{$\begin{array}{l}\text { Evaporation-weighted average percent difference between measured and modeled cumulative bare soil } \\
\text { evaporation }(\%)\end{array}$} & -4.2 & - \\
\hline
\end{tabular}

Table 13. Measurements of Bare Soil Evaporation Compared to FAO 56 Simulated Bare Soil Evaporation. Simulation Series 3.

\begin{tabular}{|c|c|c|c|c|c|c|c|}
\hline & $\begin{array}{r}\text { Ritchie } \\
(1972)\end{array}$ & $\begin{array}{l}\text { Parlange et al. } \\
\quad(1992)\end{array}$ & \multicolumn{3}{|c|}{$\begin{array}{l}\text { Howell et al. } \\
\quad(1995)\end{array}$} & $\begin{array}{l}\text { Wright (personal } \\
\text { communication, 2001) }\end{array}$ & $\begin{array}{c}\text { Farahani and } \\
\text { Bausch (1995) }\end{array}$ \\
\hline Measured cumulative bare soil evaporation (mm) & 24.2 & 16.8 & 52.8 & 93.7 & 81.2 & 117.9 & 60.3 \\
\hline $\begin{array}{l}\text { Modified FAO-56 modeled cumulative bare soil } \\
\text { evaporation }(\mathrm{mm})\end{array}$ & 24.6 & 16.1 & 52.5 & 88.9 & 85.6 & 116.8 & 49.7 \\
\hline \multirow{2}{*}{$\begin{array}{l}\text { Percent difference between measured and modeled } \\
\text { cumulative } E\end{array}$} & $1.6 \%$ & $-4.0 \%$ & $-0.6 \%$ & $-5.1 \%$ & $5.4 \%$ & $-0.9 \%$ & $17.6 \%$ \\
\hline & & & & & & $\begin{array}{l}\text { Without } \\
\text { Ritchie }\end{array}$ & All data sets \\
\hline \multicolumn{6}{|c|}{$\begin{array}{l}\text { Evaporation-weighted average percent difference between measured and modeled cumulative bare soil } \\
\text { evaporation }\end{array}$} & $-3.1 \%$ & $-2.8 \%$ \\
\hline
\end{tabular}


Yolo clay loam soil, with a $\mathrm{TEW}_{2}$ of $6 \mathrm{~mm}$, as opposed to the $\mathrm{TEW}_{2}$ range of $18-25 \mathrm{~mm}$ for silt loam soil in Table 7.

Although not tested, it may have been possible to obtain bestfit parameters for the Series 3 simulations closer to expected ranges in value had the $Z_{e}$ parameter, representing the depth of drying in the profile at the end of stage 2 , been allowed to vary more. However, what seems crucial is that the overall benefit of using best-fit soil parameters (Table 13), rather than general (Table 11) or scientist-reported (Table 12) soil parameters, appears to be rather modest. Furthermore, in order to identify bestfit soil parameters, one must have a complete bare soil evaporation data set for optimizing the specific FAO-56 model soil parameters. If such a data set is not readily available, it is likely that the potential improvement in simulation would likely be overshadowed by the cost and effort required to obtain the data.

3. The average evaporation weighted errors indicate that the model underestimates bare soil evaporation by about $7 \%$ (Tables 11-13). This said, the relatively sparse number of bare soil evaporation data sets that were available for this evaluation does not allow one to conclude a bias for the FAO-56 evaporation model to overestimate or underestimate bare soil evaporation using the published model parameters.

4. To assess a $95 \%$ confidence interval containing model error may result in an erroneous measure of the model accuracy, simply due to the limited number of available data sets. Instead, it may be better to look at the nonevaporation weighted percent differences and to use observed errors to generalize the potential model accuracy.

The Series 1 simulations (using soil parameters defined in Table 7 and the CALFED/ARI Evaporation Study method for grouping the soil types) can be used as an approximation of expected error. Some percent differences between the measured and modeled cumulative bare soil evaporation were high $(8.9 \%)$ and some were low $(-20.2 \%)$. From this range, we estimate the general accuracy of the FAO-56 model, when applied with general estimates of soil parameters, to be about $\pm 15 \%$.

\section{Conclusions}

The measured and the two- and three-stage FAO-56 simulated E/ETo and cumulative bare soil evaporation trends and values were similar for each of the three methods used for defining soil simulation parameters. All other things being equal, the Series 2 simulation using measured soil parameters tended to give similar results to the Series 1 simulation that used generalized soil parameters. The Series 3 simulation indicated that the soil parameters can be varied from general or measured values to obtain somewhat better correlations - even though there may not be a logical justification for individual parameter values except to obtain better correlations. Specifically, the average evaporation weighted percent difference between the measured and the simulated cumulative evaporation was $-4.2 \%$ for the Series 2 simulations and -7.3 and $-3.1 \%$ for the Series 1 and Series 3 simulations, respectively, for data sets that were directly comparable.

The tendency for the model to underestimate bare soil evaporation for the data sets in this evaluation by $7 \%$ does not necessarily mean that the FAO-56 model will always underestimate evaporation since the number of possible data sets evaluated (7) was relatively small. Simulations of some of the data sets resulted in an overestimate and some resulted in an underestimate of the cumulative evaporation measurements. Therefore this evaluation does not conclusively indicate that the FAO-56 model has a bias when simulating bare soil evaporation.

Rather than identifying the statistical accuracy of the model for predicting bare soil evaporation using the relatively sparse number of identified data sets, the accuracy may be best estimated by general comparison of the measured and simulated evaporation. For the simulations that used the general soil parameters published in FAO-56 (Series 1), it appears that the model is accurate to about $\pm 15 \%$ based on the largest overestimate and the largest underestimate of the cumulative bare soil evaporation.

For bare soil evaporation simulations, it seems reasonable that if one has good site-specific soil parameter information for use in the FAO-56 model, the results will tend to have a modest improvement over a simulation that uses generally defined soil parameters. For broad scope evaluations of bare soil evaporation, use of generalized soil parameters seem to be dependable. The effort to obtain the site specific parameters will tend to be rewarded by only modest improvements in the evaporation estimate.

The simulations using best-fit soil parameters (Simulation Series 3) were for comparison purposes only to find the most improvement possible in model accuracy. The Series 3 simulation is artificial in nature, as the optimized parameter values tended to be outside the normal ranges expected for soils. The results were only slightly better than for the other two simulation series.

\section{References}

Allen, R. G. (1998). "The revised FAO procedure for estimating crop evapotranspiration." Imperial Irrigation District Water Use Assessment for the Years 1987-1996, Appendix A3.3 of Water Study Team, A3.64-A3.82.

Allen, R. G., Pereira, L. S., Raes, D., and Smith, M. (1998). "Crop evapotranspiration; Guidelines for computing crop water requirements." FAO Irrigation and Drainage Paper No. 56, Rome, Italy.

Allen, R. G., Pereira, L. S., Smith, M., Raes, D., and Wright, J. L. (2005). "FAO-56 dual crop coefficient method for predicting evaporation from soil and application extensions." J. Irrig. Drain. Eng., 131(1), $\mathrm{xxx}-\mathrm{xxx}$

Allen, R. G., Smith, M., Pereira, L. S., Raes, D., and Wright, J. L. (2000). "Revised FAO procedures for calculating evapotranspiration, with testing in Idaho." ASCE Watershed Management Conf., Ft. Collins, Colo., Published on CD-ROM.

Burt, C. M., Mutziger, A. J., Howes, D. J., and Solomon, K. H. (2002). Evaporation from irrigated agriculture land in California. A study funded by the CALFED and the California State University/ Agricultural Research Inititiative. Available on the web page 〈http:// www.itre.org/reports/reportsindex.html . Irrigation Training and Research Center. California Polytechnic State Univ. San Luis Obispo, Calif.

Colorado Agricultural Meteorological Network (CoAgMet) weather data. (2001). 〈http://ccc.atmos.colostate.edu/ coag/〉 (verified May 10, 2001).

"Daily CIMIS weather data." (2001a). 〈http://www.Ipm.ucdavis.edu/ WEATHER/wxretrieve.html (verified May 10, 2001).

Eching, S., and Moellenberndt, D. (1998). Technical elements of CIMIS. The California Irrigation Management Information System. State of California, The Resources Agency, Department of Water Resources, Division of Planning and Local Assistance. Sacramento, Calif.

Farahani, H. J., and Bausch, W. C. (1995). "Performance of evapotranspiration models for maizbare soil to closed canopy." Trans. ASAE, 38(4), 1049-1059.

"Hourly CIMIS weather data." (2001b). Telnet session to "aviion.water.ca.gov" using CIMIS registered user name and pass- 
word. CIMIS helpline (800) $922-4647$ or direct line to Simon Eching (916-327-1836) (verified May 10, 2001).

Howell, T. A., Steiner, J. L., Schneider, A. D., and Evett, S. R. (1995). "Evapotranspiration of irrigated winter wheat-Southern Plains." Trans. ASAE, 38(3), 745-759.

National Oceanic and Atmospheric Administration, National Climatic Data Center (2001).828-271-4800, orders@ncdc.noaa.gov, or 〈http:// www.ncdc.noaa.gov// (verified May 10, 2001).

Parlange, M. B., and Katul, G. G. (1992). "Estimation of the diurnal variation of potential evaporation from a wet bare soil surface." $J$. Hydrol., 132, 71-89.

Parlange, M. B., Katul, G. G., Cuenca, R. H., Kavvas, M. L., Nielsen, D. R., and Mata, M. (1992). "Physical basis for a time series model of soil water content." Water Resour: Res., 28, 2437-2446.
Pruitt, W. O., and Doorenbos, J. (1977). Proc., Int. Round Table Conf. on "Evapotranspiration," Budapest, Hungary.

Ritchie, J. T. (1972). "Model for predicting evaporation from a crop with incomplete cover." Water Resour. Res., 8, 1204-1213.

Snyder, R., Bali, K., Ventura, F., and Gomez-MacPherson, H. (2000). "Estimating evaporation from bare or nearly bare soil." J. Irrig. Drain. Eng., 126(6), 399-403.

USDA-NRCS Soil Survey Division Official Soil Series Descriptions Data Access web site. (2001). 〈http://www.statlab.iastate.edu/soils/osd/> (verified May 10, 2001).

Water Study Team. (1998). Imperial irrigation district water use assessment for the years 1987-1996, Received via Freedom of Information Act.

Wright, J. L. (1982). "New evapotranspiration crop coefficients." J. Irrig. Drain. Eng., 108(1), 57-74. 